Iwona Zarzyka

\title{
EFFECT OF BORATE GROUPS ON THE PROPERTIES OF RIGID POLYURETHANE FOAMS OBTAINED WITH USING HYDROXYPROPYL DERIVATIVES OF UREA
}

Department of Organic Chemistry, Faculty of Chemistry, Rzeszow University of Technology, 6, Powstancow Warszawy Al., 35-959 Rzeszow, Poland; izarzyka@prz.edu.pl

Received: November 05, 2012 / Revised: J anuary 16, 2013 / Accepted: M arch 12, 2013

(c) Zarzyka I., 2013

\begin{abstract}
By using hydroxypropyl derivatives of urea esterified with boric acid as polyol components and 4,4'-diphenylmethane diisocyanate the rigid polyurethane foams have been obtained. The influence of boron and nitrogen atoms on the properties of foams, inter alia compressive strength and flammability, has been discussed. The presence of borate groups enhances the compressive strength of polyurethane foams meaningfully. However, the flammability of foams is determined by the participation of carbamide groups mainly.
\end{abstract}

Keywords: rigid polyurethane foams, hydroxypropyl derivatives of urea, boric acid, modification of structure, reduction of flammability, compressive strength.

\section{Introduction}

The analysis of the literature data indicated that the use of borates in the foam compositions causes a significant increase of their compressive strength. The use of boric acid derivatives creates a more ordered structure of the polymers and thus reduces the brittleness of materials [1]. Furthermore, the use of boron compounds increases the oxygen index and the retention of foams [2].

Incombustibility is one of the most important properties of polymer materials. The reduction of polymer flammability can be achieved by introducing flame retardants [3]. Retardants used in the polymer production usually worsen the properties of the obtained products and are not eco-friendly $[3,4]$. However, the European Union seeks to eliminate halogen methods of decreasing the flammability of polymeric materials and introduce such flame retardants the application of which would allow to obtain the materials of the desired mechanical properties [5-8]. Because of that boric acid becomes more and more important factor in the production of flame retardants $[9,10]$.
In my study the rigid foamed polyurethane plastics were obtained by using hydroxypropyl derivatives of urea esterified with boric acid (III) as polyol components. The influence of the presence of boron and nitrogen on the properties of polyurethane foams prepared from hydroxypropyl derivatives of urea boron modified and unmodified has been compared.

\section{Experimental}

\subsection{Syntheses}

\subsubsection{Reactions of $\mathbf{N}, \mathbf{N}$ '-bis(2-hydroxypropyl) urea with boric acid}

In a round bottom flask $88 \mathrm{~g}(0.5 \mathrm{~mol}) \mathrm{N}, \mathrm{N}$ '-bis(2hydroxypropyl)urea (BHPU), obtained according to [11] and $62 \mathrm{~g}$ (1.0 mol) boric acid (BA, pure, POCH, Poland) were placed. The reaction mixture was stirred mechanically at $383 \mathrm{~K}$. The progress of the reaction was monitored by determination of weight loss of the reaction mixture.

\subsubsection{Reactions of BHPU esterified with BA with an excess of propylene carbonate}

In a $250 \mathrm{~cm}^{3}$ three-necked round bottom flask $132 \mathrm{~g}(0.5 \mathrm{~mol})$ BHPU esterified with boric acid (EBU) and the appropriate amount of propylene carbonate (PC, pure, Fluka, Switzerland) were placed to reach the molar ratio of reagents of $1: 6$ or $1: 12$ and $6.2 \mathrm{~g}$ potassium carbonate $(12.4 \mathrm{~g} / \mathrm{mol} \mathrm{EBU}, 0.09 \mathrm{~mol} / \mathrm{mol} \mathrm{EBU})$ was added. The reaction mixture was stirred mechanically at $453 \mathrm{~K}$ with monitoring of the reaction progress by determination of unreacted PC [12]. 


\subsubsection{Reactions of BHPU with an excess of PC}

In a $250 \mathrm{~cm}^{3}$ three-necked round bottom flask $132 \mathrm{~g}(0.5 \mathrm{~mol})$ BHPU and the appropriate amount of PC (pure, Fluka, Switzerland) were placed to reach the molar ratio of reagents of $1: 6$ or $1: 12$ and $8.3 \mathrm{~g}$ potassium carbonate (16.5 g/mol BHPU, $0.12 \mathrm{~mol} / \mathrm{mol}$ BHPU) was added. The reaction mixture was stirred mechanically at $433 \mathrm{~K}$ with monitoring of the reaction progress by determination of unreacted PC [12].

\subsubsection{Foam preparation}

Attempts of foaming of the polyols obtained were carried out in small $250 \mathrm{~cm}^{3}$ test cups at room temperature. To $10 \mathrm{~g}$ of hydroxypropyl derivatives of urea, $0.1 \mathrm{~g}$ of surfactant (Silicon L6900, Momentive, US), 1.5-2.3 wt \% of triethylamine (TEA) catalyst (pure, Avocado, Germany), and 2-3 wt \% of water were added. After careful mixing of the components, a pre-weighed amount of 4,4'-diphenylmethane diisocyanate (pure, Merck, Germany) was added. Each composition was vigorously mixed until it started to cream (see Table 2).
The samples for testing were cut out from the foams thus obtained after ca. $48 \mathrm{~h}$.

\subsection{Analytical Methods}

Thermal analyses (DTG and TG) of polyurethane foams were performed in ceramic crucible, in the temperature range of $293-873 \mathrm{~K}$, on app. $2 \mathrm{mg}$ sample, under a nitrogen atmosphere with Termowaga TGA/DSC 1 derivatograph, Mettler.

The following properties of foams were determined: apparent density [13], dimensions stability [14], compressive strength [15], oxygen index [16] and thermal resistance as the weight loss after heating at 423 , 448 and $473 \mathrm{~K}$ for a month (to reach constant weight).

\section{Results and Discussion}

In reactions of $\mathrm{N}, \mathrm{N}$ '-bis(2-hydroxypropyl)urea (BHPU, I) with boric acid (BA) and subsequently with an excess of PC (Table 1, synth. 3 and 4) hydroxypropyl derivatives with carbamide group modified with boron (III) were obtained:

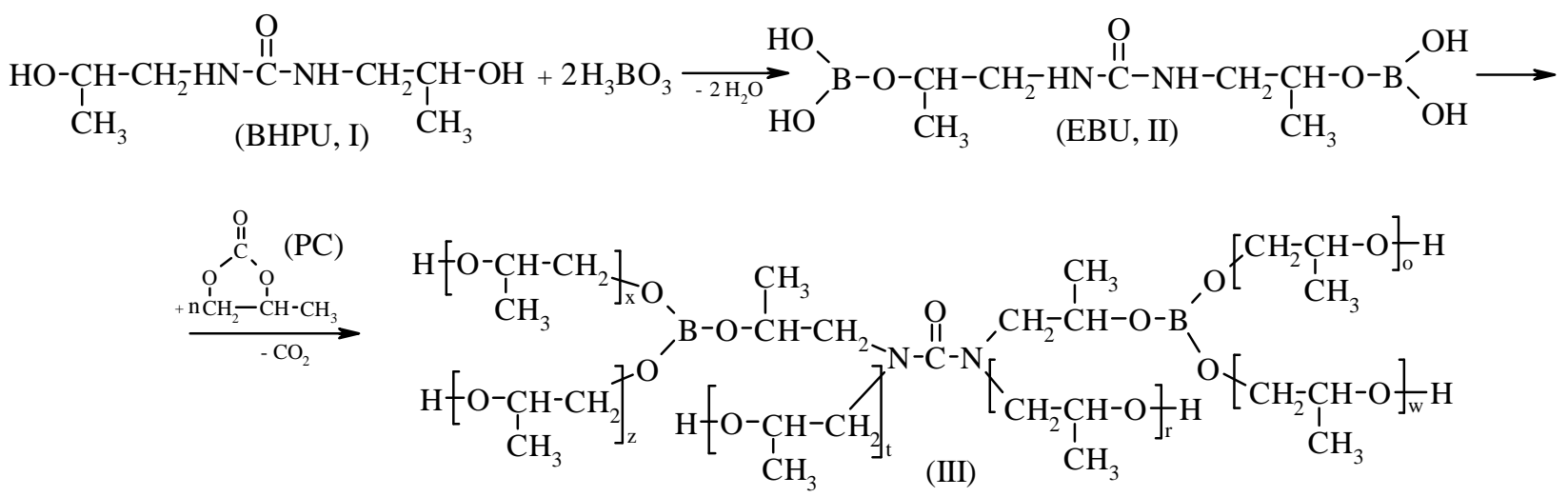

where: $\mathrm{x}+\mathrm{z}+\mathrm{o}+\mathrm{t}+\mathrm{r}+\mathrm{w} \leq 6$ or 12

Simultaneously, under the similar conditions hydroxypropyl derivatives of urea without boron (IV) were obtained too (Table 1, synth. 1 and 2).

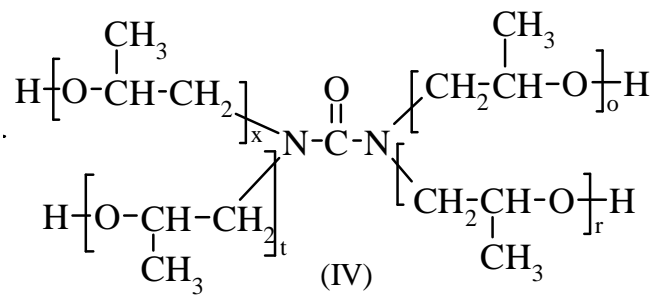

where: $\mathrm{x}+\mathrm{o}+\mathrm{t}+\mathrm{r} \leq 8$ or 14 
Table 1

\section{Reaction conditions of polyols preparation}

\begin{tabular}{|c|c|c|c|c|c|}
\hline Synth. & $\begin{array}{c}\text { Initial molar } \\
\text { ratio } \\
\text { BHPU: BA:PC }\end{array}$ & $\begin{array}{c}\text { Amount of } \\
\mathrm{K}_{2} \mathrm{CO}_{3}, \\
\text { mol /mol } \\
\text { BHPU }\end{array}$ & $\begin{array}{c}\text { Temperature, } \\
\mathrm{K}\end{array}$ & $\begin{array}{c}\text { Reaction } \\
\text { time, } \mathrm{h}\end{array}$ & $\begin{array}{c}\text { Molar ratio BHPU:x } \\
\text { in post-reaction mixture }\end{array}$ \\
\hline 1 & $1: 0: 6$ & 0.12 & 433 & 17 & $1: 5.7$ \\
\hline 2 & $1: 0: 12$ & 0.12 & 433 & 22 & $1: 11.3$ \\
\hline 3 & $1: 2: 6$ & 0.09 & 453 & 10 & $1: 5.6$ \\
\hline 4 & $1: 2: 12$ & 0.09 & 453 & 14 & $1: 1$ \\
\hline
\end{tabular}

Note: $\mathrm{x}$ - oxypropylene unit

Table 2

\section{Parameters of foaming process}

\begin{tabular}{|c|c|c|c|c|c|c|c|}
\hline \multirow{3}{*}{$\begin{array}{c}\text { Molar ratio of } \\
\text { BHPU:BA:PC in polyo }\end{array}$} & \multirow{3}{*}{ Comp. } & \multicolumn{3}{|c|}{ Composition, g/100 g polyol } & \multirow{2}{*}{\multicolumn{3}{|c|}{$\begin{array}{c}\text { Course of foaming } \\
\text { Time, } \mathrm{s} \\
\end{array}$}} \\
\hline & & \multirow{2}{*}{ isocyanate } & \multirow{2}{*}{ water } & \multirow{2}{*}{ catalyst $^{* *}$} & & & \\
\hline & & & & & creaming $^{\mathrm{a}}$ & expanding $^{\mathrm{b}}$ & drying $^{c}$ \\
\hline $1: 0: 6$ & $\mathrm{~F} 1(6)$ & 220 & 2 & 1.54 & 10 & 10 & 1 \\
\hline $1: 0: 12$ & $\mathrm{~F} 1(12)$ & 144 & 2 & 2.11 & 15 & 34 & 1 \\
\hline $1: 2: 6$ & $\mathrm{~F} 2(6)$ & 268 & 3 & 1.73 & 32 & 90 & 10 \\
\hline $1: 2: 12$ & $\mathrm{~F} 2(12)$ & 200 & 3 & 2.30 & 28 & 60 & 73 \\
\hline
\end{tabular}

Notes: * 4,4' diphenylmethane diisocyanate; $* *$ triethylamine; ${ }^{a}$ the time elapsed from the moment of mixing to the start of volume expansion; ${ }^{b}$ the time from the start of expansion to the moment of reaching the sample final volume; ${ }^{c}$ the time from reaching by the sample its final volume to the moment of losing its surface adhesion to powdered substances.

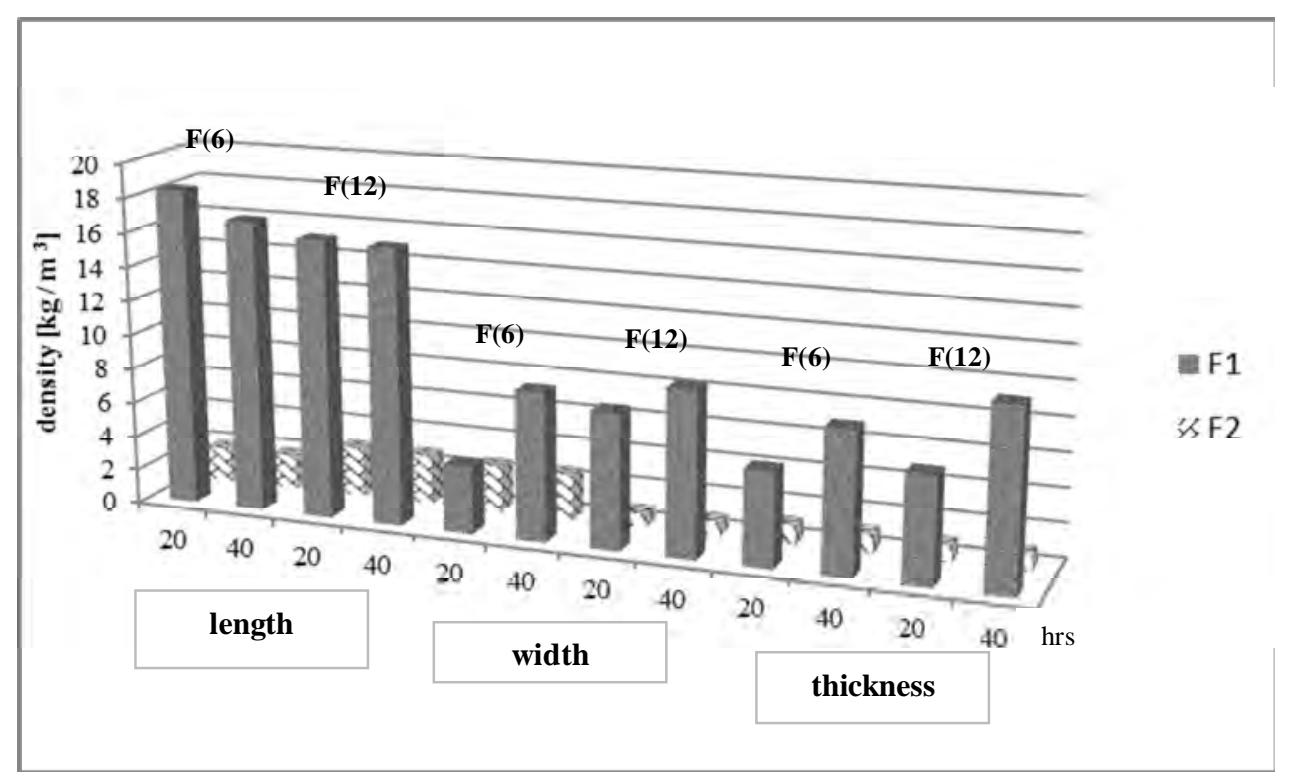

Fig. 1. Change of linear dimensions of polyurethane foams 
The obtained hydroxypropyl derivatives of urea with and without boron were applied as polyols components in preparation of polyurethanes foams. Foaming was carried out in small laboratory scale (Table 2).

It was found that apparent density of all foams was typically in the range of $32-45 \mathrm{~kg} / \mathrm{m}^{3}$. The foams obtained with the participation of boron were characterized by slightly higher apparent density $\left(38-45 \mathrm{~kg} / \mathrm{m}^{3}\right)$ than the foams without boron $\left(32-42 \mathrm{~kg} / \mathrm{m}^{3}\right)$.

The foams with boron were characterized by good dimensional stability (Fig. 1). The changes of their linear dimensions depended considerably on the content of boron in the polyol component and the changes did not exceed 1.2 or 3.8 linear \% for F2(12) and F2(6), respectively. The dimensions changes of foams which did not contain boron were much larger (Fig. 1).

Thermogravimetric analysis confirmed high thermal stability of polyurethane foams. The $5 \%$ weight loss occurred at 453 and $493 \mathrm{~K}$ in case of foams unmodified and boron modified, respectively. The temperature of maximum decomposition was similar for all foams being within the range of 533-588 K.

The thermal stability of the foams was also monitored by using static method, i.e. by measuring the weight loss upon 30 days annealing at the temperatures 423,448 and $473 \mathrm{~K}$ (Table 3). It was found that weight loss increased with temperature of test. The constant weight was generally observed after ca 18 days at every temperature. The lowest weight loss indicated the foams obtained from polyols modified with boron; here the weight loss at $423 \mathrm{~K}$ was about $6.5 \mathrm{wt} \%$, at $448 \mathrm{~K}$ it was ca. $23.5 \mathrm{wt} \%$, while at $473 \mathrm{~K}$ it was $40 \mathrm{wt} \%$ (Table 3, comp. F2(6)). If the boron content in foams was lower the weight loss of foams was slightly higher. The weight loss of the foams obtained from the polyols without boron was much higher (Table 3, comp. F1(6) and F1(12)). The thermal resistance of all foams (modified and unmodified with boron) decreased with the increase of excess of PC used for the synthesis of polyols.

Table 3

Thermal stability of polyurethane foams measured by weight loss after annealing during 30 days

\begin{tabular}{|l|c|c|c|}
\hline \multirow{2}{*}{ Comp. } & \multicolumn{3}{|c|}{$\begin{array}{r}\text { Weight loss (wt \%) of polyurethanes foams } \\
\text { after exposition at temperature, K }\end{array}$} \\
\cline { 2 - 4 } & 423 & 448 & 473 \\
\hline F1(6) & $21.57 \pm 0.13$ & $29.47 \pm 0.06$ & $42.96 \pm 0.20$ \\
\hline F1(12) & $24.74 \pm 0.02$ & $26.75 \pm 0.04$ & $45.81 \pm 0.10$ \\
\hline F2(6) & $6.52 \pm 0.01$ & $23.61 \pm 0.91$ & $39.93 \pm 1.30$ \\
\hline F2(12) & $7.54 \pm 0.23$ & $23.86 \pm 0.01$ & $42.71 \pm 0.29$ \\
\hline
\end{tabular}

The obtained foams were the subject of strength tests before temperature exposure and after annealing at $423 \mathrm{~K}$. The compressive strength was measured in the opposite direction to the direction of foams growth. The foams with boron had a compressive strength within the range of $0.10-0.22 \mathrm{MPa}$ (Fig. 2) and it was increased in comparison to the foams without boron $\left(\sigma_{M}=0.04 \mathrm{MPa}\right)$.

The foams compressive strength depended on boron content. The higher compressive strength was shown by the foams with lower boron content (Fig. 2, F2(12)). The foams compressive strength increased considerably after heating for 30 days at the temperature of $423 \mathrm{~K}$ from 60 to $340 \%$ in case of foams with boron and from 370 to $600 \%$ in case of foams without boron. In spite of that the foams compressive strength obtained without boron presence was considerably lower.

Comparing the values of oxygen index (IO) of foams modified and unmodified with boron the impact of the boron presence on oxygen index value only in case of foams obtained from a polyol component containing a smaller amount of nitrogen was noticed (Fig. 3).

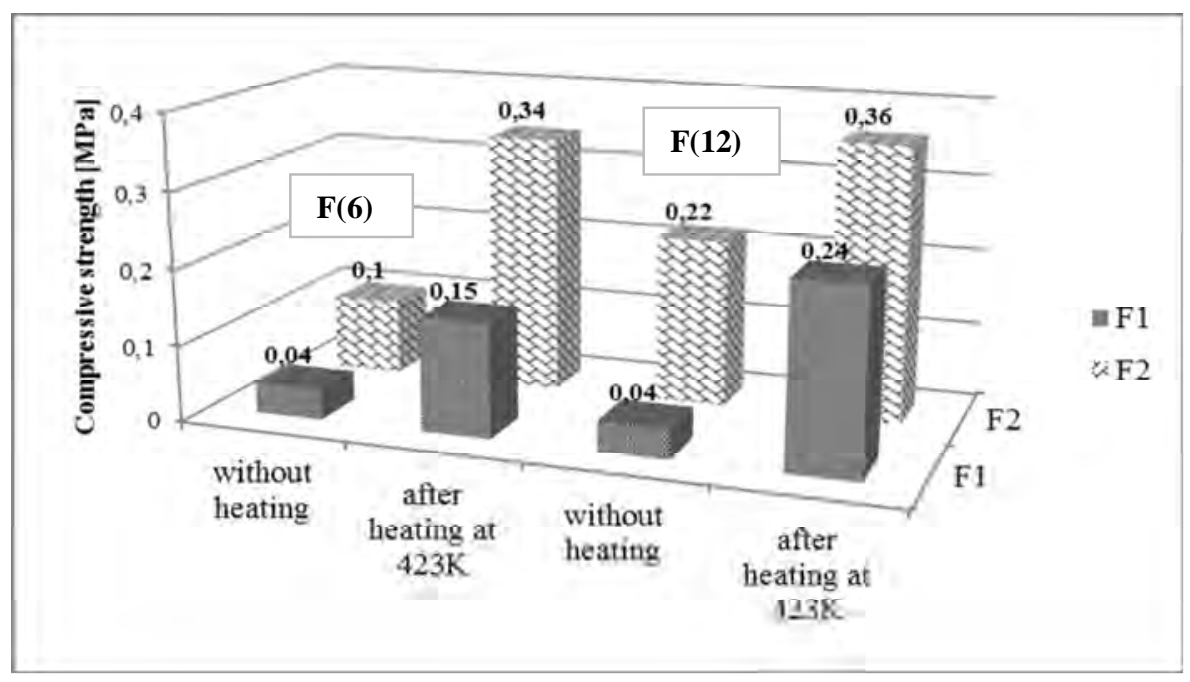

Fig. 2. Compressive strength of polyurethane foams (MPa) measured at $10 \%$ deformation 


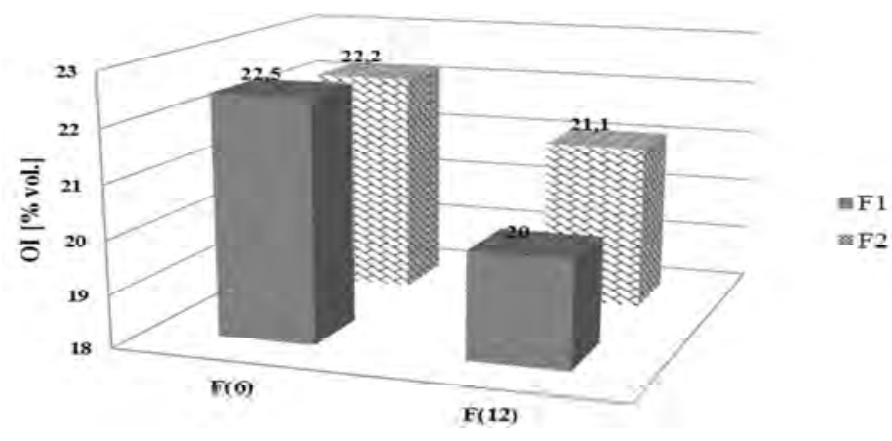

Fig. 3. Oxygen index of polyurethane foams

The determined OI values showed that the presence of nitrogen (urea groups) in foams reduces their combustibility considerably; OI values were in the range of 21.1-22.2 vol \%, whereas the value of OI of typical polyurethane foams obtained with participation of Rokopol RF-55 and 4,4'-diphenylmethane diisocyanate equals to 19.6 vol \% [2].

When the nitrogen content in the polyol was about $5 \mathrm{wt} \%$ no effect of boron presence on reducing foams flammability was observed. Foams with higher participation of nitrogen unmodified with boron had slightly higher value of the OI than the foams modified with boron (Fig. 3, F1(6) and F2(6)). Boronmodified foams obtained from polyols containing less content of nitrogen $(\leq 3.2 \mathrm{wt} \%)$ had higher OI value compared to unmodified foams (Fig. 3, F2(12) and F1(12)). However, the OI value was smaller in comparison with OI value of foams with higher content of nitrogen.

On the basis of OI value (OI higher than 21 vol \%.) it has been stated that unmodified-boron and modifiedboron (F2(12)) foams are self-extinguishing [17, 18].

\section{Conclusions}

1. An introduction of boron into the structure of foams improves their mechanical strength and thermal stability.

2. The foams modified with boron perform better dimensions stability; changes of dimensions not exceeding 3.8 linear \%.

3. The low weight losses during annealing of foams containing boron at the temperature of $423 \mathrm{~K}$ show that these foams can be applied at such temperature.

4. The presence of nitrogen is the main reason of flammability reduction of the obtained foams. At appropriate proportions of boron and nitrogen their synergic effect on reduction of flammability of polyurethane foams is observed.

\section{References}

[1] Czuprynski B., Liszkowska J. and Paciorek-Sadowska J.: Polimery, 2004, 49, 187.

[2] Paciorek-Sadowska J., Czuprynski B. and Liszowska J.: Chemik, 2012, 4, 297.

[3] Grand A. and Wilkie C.: Fire Retardancy of Polymeric Materials. Marcel Dekker, New York 2000.

[4] Kicko-Walczak E.: Polimery, 2008, 53, 126.

[5] Kicko-Walczak E. and Jankowski P.: Polimery, 2004, 49, 747.

[6] Alonso M., Auad M. and Nutt S.: Composites A, 2006, 37, 1952.

[7] Rivera-Armenta J., Heinze Th. and Mendoza-Martinez A.: Europ. Polym. J., 2004, 40, 2803.

[9] Paciorek-Sadowska J. and Czuprynski B: J. Appl. Polym. Sci., 2006, 102, 5918.

[10] Czuprynski B., Paciorek-Sadowska J. and Liszkowska J.: Polimery, 2002, 47, 727.

[11] Zarzyka-Niemiec I. and Narog D.: Przemysł Chemiczny, 2008, 87, 1048 .

[12] Kucharski M. and Kijowska D.: J. Appl. Polym. Sci., 2003, 89, 104.

[13] Polish (European) Standards: PN-EN ISO 845.

[14] Polish (European) Standards: PN-EN ISO 2796.

[15] Polish (European) Standards: PN-93C/89071, ISO 884:1978.

[16] PN ISO 4589-2:1999.

[17] Betes S. and Salomon P.: J. Fire Sci., 1993, 11, 271.

[18] Baranowski W. and Koszkul J.: Przeglad Budowlany, 2006, 11, 25.

\section{ВПЛИВ БОРАТ-ГРУП НА ВЛАСТИВОСТІ ЖОРСТКИХ ПІНОПОЛІУРЕТАНІВ, ОТРИМАНИХ З ВИКОРИСТАННЯМ ГІДРОКСИПРОПІЛОВИХ ПОХІДНИХ СЕЧОВИНИ}

Анотація. За участю гідроксипропілових похідних сечовини, естерифікованих борною кислотою як поліол компонентами, та 4,4 '-дифенілметандіізоціанату, були отримані жорсткі пінополіуретани. Досліджено вплив атомів бору $і$ азоту на властивості піноуретанів, зокрема, міцність на стиснення $i$ займистість. Встановлено, що наявність борат-груп підвищуе міцність пінополіуретану на стиснення. Займистість визначається, в основному, присутністю карбамідної групи.

Ключові слова: жорсткі пінополіуретани, гідроксипропілові похідні сечовини, борна кислота, модифікачія структури, зниження займистості, міцність на стиснення. 